УДК 338.47 - 048.78 (477)

DOI: https://doi.org/10.37320/2415-3583/10.11

Піріашвілі О.Б.

кандидат економічних наук, старший науковий співробітник, ДУ «Інститут економіки та прогнозування Національної академії наук Украӥни»

Овчиннікова В.П.

провідний економіст,

ДУ «Інститут економіки та прогнозування

Національної академії наук України»

\title{
ПРОБЛЕМИ МОДЕРНІЗАЦІЇ НА ЗАЛІЗНИЧНОМУ ТРАНСПОРТІ УКРАЇНИ ${ }^{1}$
}

Однією з причин, яка гальмує інноваційний розвиток залізничного транспорту, виступає недостатній обсяг фінансування капітальних інвестицій на залізничному транспорті. У статті розглянуто питання, пов'язані з оновленням та модернізацією рухомого складу залізничного транспорту краӥни. Розглянуто структурний склад залізничного транспорту краӥни та виділено основні складники цього сектору виробничої інфраструктури національної економіки. Наведено характеристику реформ, щьо реалізуються на залізничному транспорті в сучасних умовах. Проаналізовано розподіл рухомого складу залізничного транспорту Украӥни за роками випуску та зроблено висновок про те, що парк рухомого складу значно застарілий. Розглянуто питання інвестиційного забезпечення розвитку залізничного транспорту України на сучасному етапі. Зроблено висновок про те, щзо необхідно забезпечити иільове використанням фінансових ресурсів, які виділяються на розвиток та модернізацію залізничного транспорту, а також єдиної системи управління цією структурою.

Ключові слова: виробнича інфраструктура, залізничний транспорт, рухомий склад, інвестиції, модернізація.

Постановка проблеми. Розглядаючи залізничну транспортну інфраструктуру, необхідно підкреслити, що ця система, як і вся транспортна інфраструктура, є системоутворюючою галуззю, тому що забезпечує надійність у роботі промисловості, сільському господарстві та соціальній сфері, а також поліпшує логістику, підвищує конкурентоспроможність вітчизняних підприємств і збільшує товарообіг у країні загалом. Так, можна стверджувати, що залізнична транспортна інфраструктура $\epsilon$ одним із найважливіших чинників підвищення ефективності всіх сфер соціально-економічного розвитку країни, а отже, сприяє зміцненню національної безпеки країни у цілому. При цьому конкурентоспроможність залізничного транспорту в сучасних умовах ведення бізнесу можлива лише на основі запровадження інноваційної моделі розвитку, а матеріально-технічне забезпечення залізничного транспорту країни створюється за рахунок необхідних обсягів інвестицій у розвиток та кадрового забезпечення зазначеного вище сектору виробничої інфраструктури країни.

Аналіз останніх досліджень i публікацій. Аналіз та оцінка існуючих сучасних проблем, пов'язаних із запровадженням інноваційної моделі розвитку транспортної галузі країни та визначенням стратегічних напрямів розвитку транспорту, зокрема євроінтеграційним вектором міжнародного співробітництва у сфері транспорту, знаходяться в зоні постійної уваги з боку науковців, практиків та центральних органів дер- жавної влади, що зумовлено іiї значенням для економічного зростання України (від цього залежить, зокрема, подальше зростання національного ВВП України). Так, загальним проблемам розвитку залізничного транспорту присвячено роботи таких вітчизняних учених, як Г.Д. Ейтутис, В.М. Крапов, О.І. Никифорук, А.М. Новікова, В.О. Овчиннікова, О.Г. Рудаков, О.М. Стасюк, О.М. Широкова та ін. Особливості та проблеми оновлення, модернізації та інноваційного розвитку залізничного транспорту розглянуто в роботах вітчизняних та зарубіжних учених, серед яких: А.А. Гриценко, О.А. Гриценко, В.Л. Дикань, Г.Д. Ейтутис, О.Г. Кірдіна, О.М. Кривопішин, Б.М. Лапідус, Н.Б. Малахова, К.М. Михайлеченко та ін.

Мета статті полягає у виявленні та аналізі проблем, пов'язаних із процесом модернізації на залізничному транспорті країни, та розробленні шляхів вирішення зазначених проблем на сучасному етапі розвитку національної економіки.

Виклад основного матеріалу. Слід зазначити, що залізнична транспортна інфраструктура практично повністю вичерпала свій економічний pесурс. Це передусім стосується полотна залізничних колій та парку рухомого складу, як вантажних і пасажирських вагонів, так і тягової сили. Так, наприклад, за останніми даними АТ «Укрзалізниці», ступінь зносу магістральних вантажних тепловозів різних серій становить 100,0\%. Зазначені тепловози знаходяться в експлуатації вже понад 30 років за нормативних термінів

\footnotetext{
${ }^{1}$ Стаття підготовлена в рамках виконання НДР відомчої (прикладної) теми: «Інституціональне забезпечення функціонування виробничої інфраструктури України» (Державний реєстраційний № 0116U005855).
} 
експлуатації не більше 20 років. При цьому 30-40\% не підлягають відновленню [1, с. 5].

Аналогічний стан справ спостерігається i 3 електропоїздами приміського призначення в Україні. Як показав аналіз, ступінь зносу цього виду транспорту в країні становить близько 85-97\%. При цьому за останні 28 років ні держава, ні місцеві органи влади (на яких покладено закупівлю і ремонт електропоїздів) на ці цілі кошти не виділяли [2, с. 2].

Відносно фізичного стану парку вантажних i пасажирських вагонів слід зазначити, що кількість вантажних вагонів, що знаходяться в експлуатації від 25 до 40 і більше років, становить близько 90\% за нормативних термінів їх експлуатацiї 15-20 років. Таке ж становище спостерігається і $з$ парком пасажирських вагонів. Близько 85\% цих вагонів давно вичерпали свій нормативний ресурс і знаходяться в експлуатації від 30 до 50 років за нормативу 25-30 років. У цілому в більш-менш в нормальному стані перебувають близько 10\% вагонів [3, с. 3]. Отже, у цих умовах гостро стоїть питання про необхідність проведення повномасштабної модернізації та оновлення всіх складників залізничного транспорту країни.

Відповідно до цього, слід розглянути в даному контексті положення ст. 22 Закону України «Про транспорт», які визначають структурний склад залізничного транспорту країни, зокрема це:

- підприємства залізничного транспорту, що здійснюють перевезення пасажирів, вантажів, багажу, пошти;

- рухомий склад залізничного транспорту;

- залізничні шляхи сполучення;

- промислові, будівельні, торговельні постачальницькі підприємства;

- навчальні заклади, технічні школи;

- дитячі дошкільні заклади;

- заклади охорони здоров'я, фізичної культури та спорту, культури;

- науково-дослідні, проєктно-конструкторські організаціі;

- підприємства промислового залізничного транспорту та інші підприємства, установи та організації незалежно від форм власності, що забезпечують його діяльність і розвиток [4, с. 20-21].

Таким чином, на основі цього нами на рис. 1 наведено та запропоновано загальну схему основних структурних складників залізничної транспортної інфраструктури країни, які потребують негайної модернізації та оновлення, й іiі основні функції на сучасному етапі соціально-економічного розвитку України. Слід зазначити, що матеріали, які публікуються в засобах масової інформації (3МI) останнім часом, досить негативно оцінюють стан справ в АТ «Укрзалізниця». Необхідно також звернути увагу на ту обставину, що ринкові механізми, які уряд намагається застосу- вати у відношенні до залізничної інфраструктури, не зовсім виправдані на практиці.

Так, у роботі [5, с. 97] відзначається, що, відповідно до традиційної економічної теорії, держава повинна втручатися в економіку, коли ринок не може ефективно вирішувати поставлене завдання. Уважається, що одне із завдань політики в процесі формування та розвитку національній інноваційної системи (НИС) - ліквідація і пом'якшення провалів ринку, з якими сам ринок не в змозі впоратися. У нашому конкретному випадку під час розроблення державної політики у сфері інноваційного розвитку на залізничній транспортній інфраструктурі необхідно враховувати не тільки специфічні особливості даного об'єкта, а й специфіку розвитку самої країни, в якій зазначена структура функціонує та розвивається.

Так, розглядаючи на рис. 1 у цілому залізничну транспортну виробничу інфраструктуру країни, слід виділити в ній два складника - основний і допоміжний. До основного складника слід віднести тягову силу рухомих складів, залізничні вагони і залізничні шляхи сполучення. До допоміжного складника залізничної інфраструктури слід віднести залізничні вокзали і станції, залізничні вузли та відстійники, залізничні депо i ремонтні майстерні, електромережі, службу постачання паливом та інші служби, що забезпечують безпечний і надійний рух поїздів на залізничних шляхах сполучення в Україні. При цьому від злагодженої роботи двох цих складників залежить як основна функція залізничного транспорту, у завдання якої входить забезпечення своєчасної, безпечної і надійної доставки вантажів та пасажирів до кінцевих пунктів їх призначення, так і те, що, відповідно, чинить позитивний вплив на підвищення ефективності соціально-економічного розвитку самої країни.

Інноваційний складник розвитку національної економіки будь-якої країни стає визначальним чинником у конкурентній боротьбі за споживача продукції (товарів та послуг) у ринкових умовах господарювання у постіндустріальному суспільстві. Тому в умовах формування національними урядами провідних країн світу цифрової та сервісної економіки, де на перший план в економічному розвитку виходить сфера послуг, транспортний сектор країни стає пріоритетним видом економічної діяльності. Відзначимо, що Україна, маючи вигідне географічне положення на Свразійському континенті, повинна максимально використовувати існуючий транспортний потенціал із перевезень вантажів та пасажирів залізничним транспортом країни.

Сучасний стан основних складників розподілу рухомого складу залізничного транспорту України за роками випуску наведено в табл. 1. Як свідчать ці дані, левова частка рухомого 


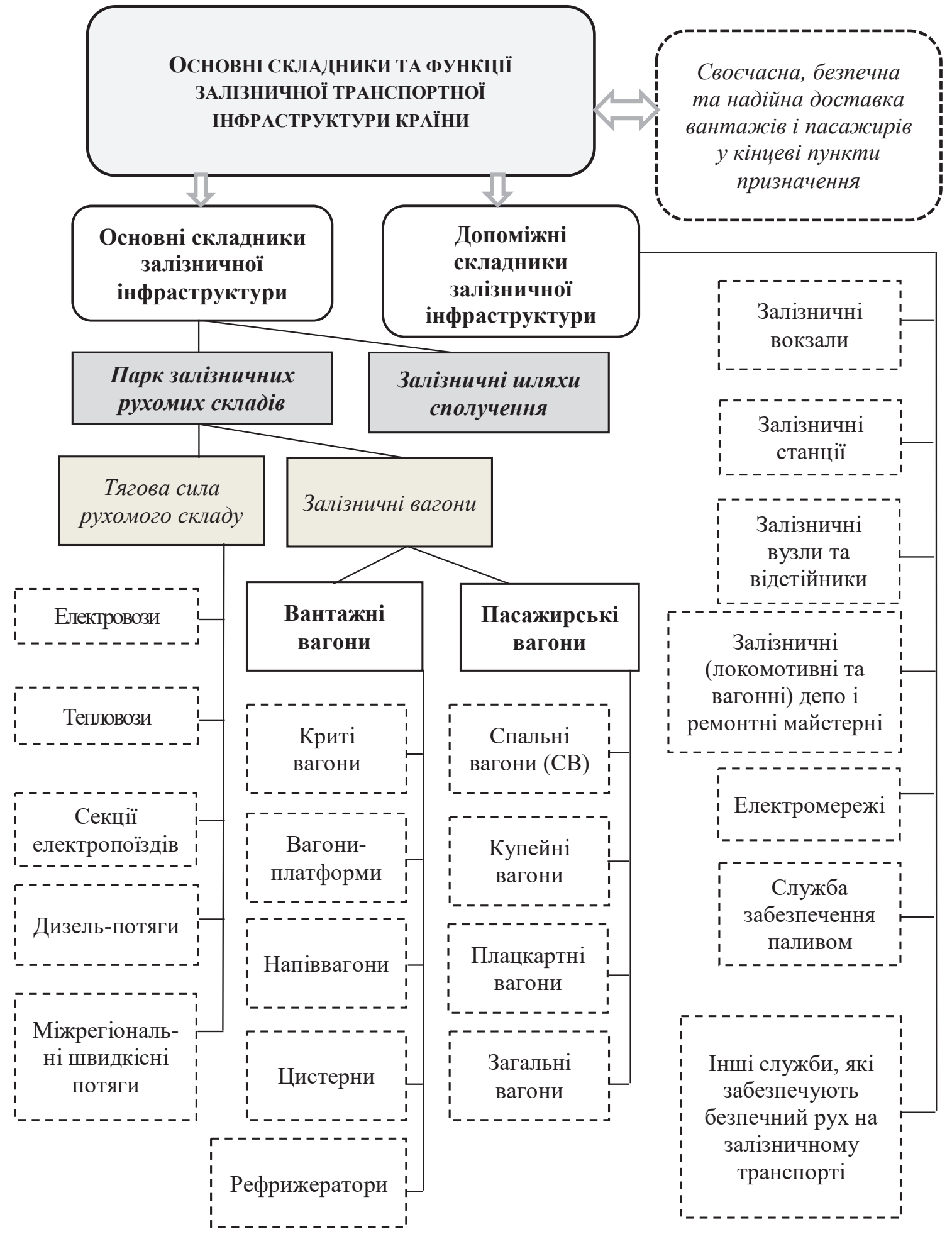

Рис. 1. Схема основних складників залізничної транспортної інфраструктури країни та ії функції

Джерело: систематизовано та складено авторами

складу залізничного транспорту України у цілому за роками випуску становила 16-25 років та 26-40 років у 2015, 2016 та 2017 рp. Зокрема, частка тепловозів до 8 років випуску становила 0,2\% у 2015 р. та 2017 р., 9-15 років випуску $0,1 \%$ у 2015 р. та $7,1 \%$ у 2017 р., $16-25$ років випуску $-18,3 \%$ у 2015 р. та 60,0\% у 2017 p.
Проте левова частка тепловозів припадає на 26-40 років випуску, зокрема 66,0\% у 2015 р., $77,5 \%$ у 2016 р. та $32,3 \%$ у 2017 р. до загальної кількості тепловозів. Частка тепловозів більше 40 років випуску становила $15,4 \%$ у 2015 р. та $0,4 \%$ у 2017 р. Щодо парку електровозів, то ситуація склалася так: до 8 років випуску - 4,1\% у 2015 р. 
Розподіл парку рухомого складу залізничного транспорту України

Таблиця 1 за роками випуску на кінець 2015, 2016 та 2017 рp., \%

\begin{tabular}{|c|c|c|c|c|c|c|c|}
\hline \multirow{2}{*}{$\begin{array}{c}\text { Рухомий } \\
\text { склад }\end{array}$} & \multirow{2}{*}{ Роки } & \multirow{2}{*}{ Усього } & \multicolumn{5}{|c|}{ У тому числі за роками випуску } \\
\hline & & & до 8 років & 9-15 років & 16-25 років & 26-40 років & більше 40 років \\
\hline \multirow{3}{*}{ Тепловози } & $2015 \mathrm{p}$. & 100,0 & 0,2 & 0,1 & 18,3 & 66,0 & 15,4 \\
\hline & $2016 \mathrm{p}$ & 100,0 & 0,2 & 0,3 & 6,5 & 77,5 & 15,5 \\
\hline & $2017 \mathrm{p}$ & 100,0 & 0,2 & 7,1 & 60,0 & 32,3 & 0,4 \\
\hline \multirow{3}{*}{ Електровози } & $2015 \mathrm{p}$ & 100,0 & 4,1 & 3,6 & 5,2 & 34,1 & 53,0 \\
\hline & $2016 \mathrm{p}$. & 100,0 & 4,0 & 3,7 & 2,1 & 37,1 & 53,1 \\
\hline & $2017 \mathrm{p}$ & 100,0 & 5,4 & 2,9 & 4,5 & 33,2 & 54,0 \\
\hline \multirow{3}{*}{ Паровози } & $2015 \mathrm{p}$ & 100,0 & - & - & - & - & 100,0 \\
\hline & $2016 \mathrm{p}$ & 100,0 & - & - & - & - & 100,0 \\
\hline & 2017 p. & 100,0 & - & - & - & - & 100,0 \\
\hline \multirow{3}{*}{$\begin{array}{l}\text { Вантажні } \\
\text { вагони }\end{array}$} & $2015 \mathrm{p}$ & 100,0 & 5,6 & 2,1 & 26,3 & 63,8 & 2,2 \\
\hline & 2016 p. & 100,0 & 4,9 & 3,3 & 19,4 & 70,1 & 2,3 \\
\hline & 2017 p. & 100,0 & 6,1 & 4,6 & 15,0 & 71,9 & 2,4 \\
\hline \multirow{3}{*}{$\begin{array}{l}\text { Пасажирські } \\
\text { вагони }\end{array}$} & $2015 \mathrm{p}$ & 100,0 & 4,5 & 3,6 & 12,7 & $18,7^{* *}$ & $60,5^{* * *}$ \\
\hline & $2016 \mathrm{p}$ & 100,0 & 3,8 & 4,8 & 8,1 & $20,3^{* *}$ & $63,0^{* * * *}$ \\
\hline & 2017 p. & 100,0 & 1,8 & 7,6 & 1,7 & 21,0 & 67,9 \\
\hline
\end{tabular}

** 26-28 років.

*** Більше 28 років.

Джерело: складено авторами на основі даних [6-8]

та 5,4\% у 2017 р., 9-15 років випуску - 3,6\% у 2015 р. та $2,9 \%$ у 2017 р., а також 16-25 років випуску - 5,2\% у 2015 р. та 4,5\% у 2017 р. Слід також підкреслити, що третина електровозів в Україні припадає на 26-40 років випуску та близько $50 \%$ - це більше 40 років випуску, а саме: $26-40$ років випуску - 34,1\% у 2015 р. та $33,2 \%$ у 2017 р., більше 40 років випуску - 53\% у 2015 р. та 54\% у 2017 р. до загальної кількості електровозів у країні.

Ситуація, що склалася на залізничному транспорті в країні з віком вантажних вагонів, виглядає більш оптимістично, ніж із локомотивним парком на сучасному етапі розвитку. Так, частка вантажних вагонів до 8 років випуску становила 5,6\% у 2015 p. та $6,1 \%$ у 2017 p., $9-15$ років випуску $2,1 \%$ у 2015 р. та $4,6 \%$ у 2017 р., $16-25$ років випуску $-26,3 \%$ у 2015 р. та $15,0 \%$ у 2017 р. Разом із цим зазначимо, що левова частка вантажних вагонів у країні припадає на 26-40 років випуску. Так, зокрема, частка вантажних вагонів віком $26-40$ років випуску становила $63,8 \%$ у 2015 р. та $71,9 \%$ у 2017 р. Частка вантажних вагонів віком більше 40 років випуску становила 2,2\% у 2015 p. та 2,4\% у 2017 р. до загальної кількості вантажних вагонів у країні.

Більш критичною, на нашу думку, виглядає ситуація щодо вікового стану пасажирських вагонів за період, що аналізується. Так, частка пасажирських вагонів віком до 8 років випуску становила $4,5 \%$ у 2015 р. та $1,8 \%$ у 2017 р., 9-15 років випуску - 3,6\% у 2015 р. та 7,6\% у 2017 р., 16-25 років випуску - 12,7\% у 2015 р. та 1,7\% у 2017 р. Разом із цим слід зазначити, що частка пасажирських вагонів віком 26-28 років випуску в країні становила $18,7 \%$ у 2015 р. та $21,0 \%$ у 2017 р., а частка пасажирських вагонів віком більше 28 років випуску становила $60,5 \%$ у 2015 р. та $67,9 \%$ у 2017 p.

Таким чином, наведені вище економічні показники свідчать про те, що в Україні на сучасному етапі розвитку парк рухомого складу залізничного транспорту країни значно застарілий, що потребує оновлення і модернізації у найближчій та середньостроковій перспективі, і це має стати пріоритетним та економічно обгрунтованим напрямом подальшого економічного розвитку.

Окрім того, що стосується Закону України «Про залізничний транспорт України», законопроєкт якого був зареєстрований у Верховній Раді України 14.12.2016 за № 3650, згідно із заключенням Головного науково-експертного управління від 04.02.2016, потребує відповідного доопрацювання і внесення поправок. Разом із цим слід звернути увагу на те, що другий тип монополізму експерти пов'язують із технологічною олігополією, i це означає, що сама технологія потребує великих підприємств, у межах яких тільки й може бути організоване ефективне виробництво. Це стосується природних монополій, зокрема i залізничного транспорту країни, зміст якої визначається Законом України «Про природну монополію» від 2000 р. Зокрема, О.А. Гриценко у своїй роботі зазначає, що «...безглуздо уявити у таких галузях, як металургія, авіакосмічна галузь, залізничний транспорт, тисячі невеликих підприємств. Це суперечить 
логіці науково-технічного прогресу, виробництву конкурентоспроможної продукції. Це означає, що технологічні олігополії не можуть бути об'єктом демонополізації...» [9, с. 111-114]. Тому, на нашу думку, на сучасному етапі розвитку в певних соціально-економічних умовах така державна компанія, як АТ «Укрзалізниця», повинна функціонувати як єдиний господарюючий організм 3 єдиним центром управління та прийняття стратегічних та оперативних рішень для ефективності (прибутковості).

Проте слід зазначити, що нещодавно новий міністр інфраструктури нагадав про подальші плани, зокрема розділити АТ «Укрзалізниця» на три складники: оператора інфраструктури, вантажного перевізника та пасажирського перевізника, а також провести IPO (перший публічний продаж акцій акціонерного товариства). Зокрема, чиновник відзначив: «...буде створено конкурентний ринок залізничних перевезень та забезпечено рівноправний доступ до залізничної інфраструктури. Для цього нам потрібен новий закон про залізничний транспорт, розраховуємо на підтримку парламенту в цьому питанні...» [10, с. 1-2]. Зазначене положення, своєю чергою, передбачене Директивою ЄС 91/440 щодо системної лібералізації ринку залізничних перевезень відповідно до Угоди про асоціацію з СС та зону вільної торгівлі (далі - ЗВТ) з Свросоюзом, яку Україна підписала у 2014 р.

Унаслідок цього українська залізниця у середній та довгостроковій перспективі має пристосуватися до умов «...нової транспортної філософії, яка називається Trackage, відповідно до якої приватний перевізник, маючи власний парк вагонів та тягу, може сформувати вантажний потяг та скористатися залізничною інфраструктурою, яка знаходиться під управлінням окремого оператора. Розповсюдження Trackage визначається Директивою ЄC 2001/125, відповідно до якої формується єдина логістична система «в межах фрахту», і в рамках цієї системи для всіх учасників відкривається єдиний доступ до інфраструктури...» [11, с. 12-13].

У сучасних соціально-економічних умовах країни ОЕСР здійснюють підвищення продуктивності праці в економіці через масштабну технологічну модернізацію реального виробництва в усіх секторах національних економік. Тому поступове оновлення і модернізація парку рухомого складу української залізниці сприятимуть підвищенню продуктивності праці в даному секторі виробничої інфраструктури національної економіки. Системне недостатнє фінансування оновлення, модернізації та ремонтних робіт парку рухомого складу АТ «Укрзалізниця» призвело до катастрофічної ситуації на залізниці країни в останні роки. На нашу думку, поділ великої державної залізничної компанії на три окремі компанії призведе до ще більшого зниження конкурентоспроможності залізниці, подальшого зменшення кількості парку рухомого складу i підвищення ступеня зносу основних засобів виробництва.

Окрім того, у 2008 р. ПАТ «Укрзалізниця» (а саме науково-технічна рада «Укрзалізниці») розробила та представила «Комплексну програму оновлення залізничного рухомого складу України на 2008-2020 роки», у рамках якої передбачалося інвестувати близько 130 млрд. грн в оновлення залізничного рухомого складу [12, с. 1]. Загалом у межах зазначеної програми до 2020 р. передбачалося придбати, зокрема, понад 3,5 тис пасажирських вагонів, 442 пасажирських електровози, 125 тепловозів, 236 електропоїздів, 133 дизельпотяги та кількасот одиниць іншої пасажирської техніки. Вантажний парк рухомого складу до 2020 р. поповниться на 79,8 тис вантажних вагонів, 24,4 тис контейнерів, 765 вантажних електровозів та близько 1,5 тис одиниць маневрових та колійних машин. За попередніми даними, для виробництва більшої частини техніки вистачить потужностей вітчизняних заводів транспортного залізничного машинобудування, але частина пасажирських вагонів, електровозів та колійної техніки, яка не виробляється в Україні, буде придбана за кордоном за валюту, що, своєю чергою, не є позитивним фактом для національних товаровиробників рухомого складу для української залізниці.

Разом із цим є певні недоліки в роботі. Наприклад, у сучасних складних умовах за останній рік, за інформацією АТ «Укрзалізниця», через критичну нестачу палива «Укрзалізниця» ввела обмеження, а саме: регіональним підрозділам доручено максимально скоротити парк тепловозів, задіяних у маневровій роботі, та оптимізувати пропуск вантажних потягів по електрифікованих ділянках. Також припинено видачу дизельного палива для виконання робіт із модернізації, ремонту колії та інших робіт, пов'язаних 3 обслуговуванням інфраструктури, за винятком аварійних ситуацій. Також до відновлення постачань палива зупинене виконання всіх робіт із модернізації та ремонту інфраструктури, які потребують витрат дизельного палива.

Важливим питанням є також реалізація ефективної інвестиційної політики на залізничному транспорті країни стосовно інноваційного розвитку сектору, зокрема це пошук та оптимізація джерел фінансування капітальних інвестицій. Так, зокрема, місцеві органи влади і самоврядування у межах своїх повноважень виділяють бюджетні кошти та залучають приватний капітал для вдосконалення залізничної транспортної мережі, будівництва вокзалів тощо. Відповідно до чинного законодавства, будівництво залізничних вокзалів, залізничних станцій, пасажирських платформ, тунелів, придбання пасажирського рухомого складу, утримання й упорядкування залізничних шляхів сполучення та інших об'єктів, пов'язаних з обслуговуванням пасажирів і перевезенням вантажів, виконують за 
кошти державного та місцевих бюджетів та підприємств транспорту. Слід підкреслити, що на сучасному етапі розвитку основними джерелами фінансування капітальних інвестицій на залізничному транспорті виступають власні кошти підприємств та організацій, міжнародні кредити (кредити ЄБРР тощо), а також у формі лізингу.

Так, за інформацією інформаційного агентства «Інтерфакс-Україна», яку повідомив член правління АТ «Укрзалізниця», обсяг щорічних інвестицій на утримання залізничної інфраструктури та подальший іï розвиток мають становити приблизно 108 млрд. грн на рік [13, с. 1-2]. До того ж із посиланням на думку правління компанії, для реалізації стратегії «Укрзалізниці» на 2019-2023 рр. за базовим сценарієм необхідно близько 150 млрд. грн інвестицій. Також, за словами колишнього голови компанії Євгена Кравцова, Закон України «Про залізничний транспорт» (у новій редакції) має корелювати 3 планом реструктуризації АТ «Укрзалізниця», який буде представлено правлінням до кінця 2019 р., ключовим механізмом реалізації стратегії «Укрзалізниці» на 2019-2023 рр. є реорганізація монополіста в кілька компаній відповідно до сегментів бізнесу: пасажирський, вантажний та доступ до інфраструктури.

Висновки. Відповідно до вищевикладеного, випливає висновок про те, що становище на залізничному транспорті країни з кожним роком погіршується, незважаючи на всі розмови про реформи, що проводяться на залізниці. Водночас, 3 огляду на ту обставину, що залізнична транспортна інфраструктура $є$ системоутворюючою й одним 3 основних базових складників, що забезпечують соціально-економічний розвиток країни та їі безпеку, проблема подальшого розвитку української залізниці та іiі модернізація набуває особливого значення.

При цьому слід зауважити, що підприємства вітчизняного транспортного залізничного машинобудування займаються переважно капітальним ремонтом іноземної техніки, що була у використанні та куплена за валюту за кордоном, витрачаючи на це чималі бюджетні кошти. Водночас вельми очевидним є те, що доцільно самим виробляти парк тягової сили та рухомий склад для внутрішнього ринку України на вітчизняних виробництвах із метою забезпечення транспортної інфраструктури країни новою технікою, а саме електровозами, тепловозами, залізничними вагонами та електропоїздами власного виробництва. Тим більше що виробничі потужності для вирішення цієї проблеми в країні поки ще існують.

Слід також зазначити, що на розвиток АТ «Укрзалізниця» щорічно виділяються чималі фінансові ресурси. Однак за всі роки так званого «реформування» на залізничному транспорті ніяких суттєвих позитивних змін не тільки не відбулося, а навпаки, ситуація значно погіршилася, що свідчить лише про одне - про системне нецільове використання фінансових коштів.

Тому в цих сучасних складних умовах необхідне розроблення державних цільових програм із розвитку мережі залізничної транспортної інфраструктури країни. При цьому вони повинні здійснюватися на системному рівні, а їх реалізація повинна бути забезпечена відповідними обсягами інвестицій та найсуворішим контролем із боку центральних i регіональних органів державної влади над їх використанням, а також єдиною системою управління цією залізничною транспортною інфраструктурою країни.

Підсумовуючи, слід сказати, що під час вирішення проблеми вдосконалення системи залізничної транспортної інфраструктури необхідно розглядати ii на системному рівні в контексті інноваційного розвитку і в суворій відповідності 3 нормативно-правовою базою, яка повинна бути розроблена у цілому для всієї цієї структури, а не за окремими іiі складниками. Прийняті рішення, постанови уряду та інші укази за окремими складниками залізничної інфраструктури призводять у кінцевому підсумку до негативних наслідків роботи всієї цієї системи у цілому, тому що ці рішення не були пов'язані між собою, а іноді й суперечили одне одному. У зв'язку із цим, вирішуючи питання, що стоять перед транспортною залізничною інфраструктурою, необхідно керуватися системним підходом та поетапним вирішенням цієї проблеми, розглядаючи всю цю складну систему як єдине ціле.

Питання, пов'язані з приватизацією залізничної транспортної інфраструктури, досить проблематичні, оскільки зарубіжний досвід показує, що в більшості країн залізниці належать державі. При цьому ці національні залізниці отримують від держави величезні дотації з державного бюджету, що сприяє подальшому їх розвитку, збільшенню швидкості руху потягів та поліпшенню комфортності перевезень пасажирів у цілому.

Отже, формування та розвиток сучасних інститутів, інституцій та інститутів розвитку у сфері залізничного транспорту в Україні, розроблення методологічних підходів до дослідження та вдосконалення його інституціонального середовища $є$ актуальними науковими та прикладними завданнями на сучасному етапі розвитку національної економіки в умовах глобальних інтеграційних процесів та реформування економіки України.

I насамкінець слід підкреслити, що в сучасних ринкових умовах функціонування залізничного транспорту країни необхідно ефективно використовувати весь комплекс заходів щодо маркетингу послуг інфраструктури залізничного транспорту в Україні 3 метою максимального задоволення потреб споживачів цих послуг в умовах конкурентної боротьбі. 


\section{Список використаних джерел:}

1. Дудина А. Локомотив напоминал груду металлолома: кто виноват в новой аварии на ж/д. Вести. 2018. 17 октября. № 172(1275). С. 5.

2. Андроник В. Электрички отдадут городам? Итоги недели. 2019. 20-26 февраля. № 8(706). С. 2.

3. Петик М. В поездах становится опасно. Итоги недели. 2019. 6-12 февраля. № 6(704). С. 3.

4. Про транспорт : Закон України від 10 листопада 1994 р. №232/94-BP / Верховна Рада України. URL : https://zakon.rada.gov.ua/laws/show/232/94-\%D0\%B2\%D1\%80\#o204 (дата звернення: 25.10.2019).

5. Голиченко О.Г. Государственная политика и провалы национальной инновационной системы. Bопросы экономики. 2017. № 2. C. 97-108.

6. Транспорт і зв 'язок України. 2015 : статистичний збірник / Державна служба статистики України. Київ, 2016. С. 91. URL : http://www.ukrstat.gov.ua/ (дата звернення: 25.10.2019).

7. Транспорт і зв“язок України. 2016 : статистичний збірник / Державна служба статистики України. Київ, 2017. С. 85. URL : http://www.ukrstat.gov.ua/ (дата звернення: 25.10.2019).

8. Транспорт і зв“язок України. 2017 : статистичний збірник / Державна служба статистики України. Київ, 2018 . С. 82. URL : http://www.ukrstat.gov.ua/ (дата звернення: 25.10.2019).

9. Гриценко О.А. Монополізм, його суть, типи, форми та наслідки. Антимонопольна політика. Основи економічної теорії : підручник / О.О. Мамалуй та ін. ; за ред. О.О. Мамалуя. Київ, 2005. С. 111-114.

10. Кабмін повернув «Укрзалізницю» до сфери управління Мінінфраструктури. Інформаційне агентство ІнтерфаксУкраїна. Економіка : вебсайт. URL : https://ua.interfax.com.ua/news/economic/619575.html (дата звернення: 31.10.2019).

11. Кущ А. Разделение «Укрзалізниці». Когда из Киева в Коростень будет дешевле долететь, чем доехать. Деловая столий. 2019. № 39/957. 30 сентября. С. 12-13.

12. «Укрзалізниця» до 2020 року суттєво оновить залізничний рухомий склад. Урядовий портал : вебсайт. URL : http://old.kmu.gov.ua/kmu/control/publish/article?art_id=121660263 (дата звернення: 31.10.2019).

13. На утримання і розвиток залізничної інфраструктури необхідно 108 млрд грн на рік - член правління «Укрзалізниці». Інформаційне агентство Інтерфакс-Україна. Економіка : вебсайт. URL : https://ua.interfax.com.ua/news/ economic/620144.html (дата звернення: 06.11.2019).

\section{References:}

1. Dudina. A. (2018) Lokomotiv napominal grudu metalloloma: kto vinovat v novoy avarii na zh/d. [Lokomotiv resembled a pile of scrap metal: who is to blame for the new accident at the railway]. Vesti, no. 172(1275), pp. 5.

2. Andronik V. (2019) Elektrichki otdadut gorodam? [Electric trains will be given to cities?]. Week Results, no. 8(706), pp. 2.

3. Petik M. (2019) V poezdakh stanovitsya opasno. [The train is becoming dangerous]. Week Results, no. 6(704), pp. 3.

4. Verkhovna Rada Ukrajiny. (1994) Pro transport: Zakon Ukrajiny vid 10 lystopada 1994 roku № 232/94-VR [On Transport: Law of Ukraine of November 10, 1994 №232 / 94-VR], Kyiv: Verkhovna Rada of Ukraine. Available at: https://zakon.rada.gov.ua/laws/show/232/94-\%D0\%B2\%D1\%80\#o204 (accessed 25 October 2019).

5. Golichenko O. (2017) Gosudarstvennaya politika i provaly natsional'noy innovatsionnoy sistemy. [Public policy and national innovation system failures]. Voprosy Ekonomiki, no. 2, pp. 97-108.

6. Derzhavna sluzhba statystyky Ukrainy. (2016) Transport i zv'jazok Ukrainy - 2015: statystychnyj zbirnyk [Transport and Communications of Ukraine - 2015: Statistical yearbook], Kyiv: Informacijno-analitychne aghentstvo. Available at: http://www.ukrstat.gov.ua (accessed 25 October 2019).

7. Derzhavna sluzhba statystyky Ukrainy. (2017) Transport i zv 'jazok Ukrainy - 2016: statystychnyj zbirnyk [Transport and Communications of Ukraine - 2016: Statistical yearbook], Kyiv: Informacijno-analitychne aghentstvo. Available at: http://www.ukrstat.gov.ua (accessed 25 October 2019).

8. Derzhavna sluzhba statystyky Ukrainy. (2018) Transport i zv'jazok Ukrainy - 2017: statystychnyj zbirnyk [Transport and Communications of Ukraine - 2017: Statistical yearbook], Kyiv: Informacijno-analitychne aghentstvo. Available at: http://www.ukrstat.gov.ua (accessed 25 October 2019).

9. Ghrycenko O.A. 2005. Monopolizm, jogho sutj, typy, formy ta naslidky. Antymonopoljna polityka. [Monopoly, its essence, types, forms and consequences. Antitrust policy]. Osnovy ekonomichnoji teoriji: pidruchnyk [Fundamentals of economic theory: a textbook]. Kyiv: Jurincom Inter, pp. 111-114.

10. Informacijne aghentstvo Interfaks-Ukrajina. (2019) Kabmin povernuv «Ukrzaliznycju» do sfery upravlinnja Mininfrastruktury. [The Cabinet returned Ukrzaliznytsia to the Ministry of Infrastructure]. Veb-sajt. Available at: https://ua.interfax.com. ua/news/economic/619575.html (accessed 31 October 2019).

11. Kushch A. (2019) Razdelenie «Ukrzaliznitsi». Kogda iz Kieva v Korosten' budet deshevle doletet', chem doekhat' [Division "Ukrzaliznytsi". When it will be cheaper to fly from Kiev to Korosten than to get there]. Delovaya Stolitsa, no. 39/957, pp. 12-13.

12. Urjadovyj portal (2008) Ukrzaliznycja do 2020 roku suttjevo onovytj zaliznychnyj rukhomyj sklad. [Ukrzaliznytsia will significantly upgrade its rolling stock by 2020]. Veb-sajt. Available at: http://old.kmu.gov.ua/kmu/control/publish/article?art_ id=121660263 (accessed 31 October 2019).

13. Informacijne aghentstvo Interfaks-Ukrajina. (2019) Na utrymannja i rozvytok zaliznychnoji infrastruktury neobkhidno 108 mlrd ghrn na rik - chlen pravlinnja "Ukrzaliznyci». [The maintenance and development of railway infrastructure requires UAH 108 billion a year - a member of the board of Ukrzaliznytsia.] Veb-sajt, pp. 1-2. Available at: https://ua.interfax.com.ua/ news/economic/620144.html (accessed 06 November 2019). 
Piriashvili Alexander, Ovchinnikova Vera

State Organization «Institute of the Economy and Forecasting of the National Academy of Sciences of Ukraine»

\section{PROBLEMS OF MODERNIZATION ON THE RAILWAY TRANSPORT OF UKRAINE}

The article is devoted to pressing issues that hinder the innovative development of the country's railway transport, timely modernization and updating of rolling stock. The article discusses issues related to the updating and modernization of the rolling stock of the country's railway transport in the context of reforming this sector of the production infrastructure. In the process of this research, the authors used a systematic approach, an integrated approach, an analysis and synthesis method. The number of domestic and foreign scientists are given who consider these problems in their scientific works and classify the areas of scientific research. The characteristic is given to the current state of the rolling stock in the railway transport in Ukraine. The structural elements of railway transport are considered and the main components of this sector of the production infrastructure of the national economy are highlighted. The general scheme of the main components of the country's railway transport infrastructure at the present stage of development is given. The main and auxiliary components of the country's railway infrastructure are highlighted, and the main function of railway transport in modern conditions is also determined. The characteristic of individual norms of legislative support of the development problems is given. The characteristic of the ongoing reforms in the railway transport in modern conditions is given. The distribution of the rolling stock of the Ukrainian railway transport by years of production is analyzed and the conclusion is made that the rolling stock fleet is significantly outdated. The issue of investment support for the development of the railway transport of Ukraine at the present stage of development is considered. It is concluded that it is necessary to ensure targeted use of financial resources allocated for the development and modernization of the railway transport in the country. In a practical aspect, the results obtained should be taken into account when developing system software for the development of the railway transport infrastructure of Ukraine based on the introduction of an innovative development model.

Key words: production infrastructure, railway transport, rolling stock, investments, modernization.

JEL classification: L43, L92, O33. 